\title{
NUCLEAR PROLIFERATION IN SOUTH ASIA -TOWARDS WORLD WAR-III
}

\author{
Syed Jazib Shamim*
}

Muhammad Farooq ${ }^{* *}$

\begin{abstract}
The world witnessed a major historical event in 1947 when subcontinent, which was governed as a one unit from Khyber to Burma since almost last one thousand years, partitioned by the ruling British Empire resulting into two states namely India and Pakistan. The major reason behind partition of the subcontinent was the religious and cultural differences between the Hindus and Muslims. This difference made them hostile towards each other and India having superiority in all aspects, compelled Pakistan to become a security state right after its inception. To expand its superiority over the whole region, the Indian nuclear program started in 1944, even before its independence. India conducted first nuclear tests in 1974 and continued expanding its nuclear program. This forced Pakistan to work seriously on its nuclear program with a fast pace. India announced its formal entry to the nuclear weapons club in May 1998 with 5 nuclear tests at Pokhran, Pakistan, having nuclear capability at that time, replied back in merely two weeks with 6 nuclear tests and became the $7^{\text {th }}$ nation in the world and first Islamic country to join the nuclear countries club. The lives of over a billion people are at mercy of the two nuclear powers state heads, especially India having an extremist government poses a serious threat to the peace of subcontinent which needs great attention especially from the global community otherwise a nuclear Armageddon could be expected.
\end{abstract}

Keywords: Subcontinent, nuclear deterrence, nuclear program, Armageddon

\section{Introduction}

The world experienced the end of British rule from the mighty subcontinent in 1947, forming two newly independent states namely India and Pakistan. This historic partition displaced around 12 million inhabitants residing in the whole subcontinent claiming the lives of almost 1 million people across the subcontinent. India emerged as a secular state with a dominant Hindu majority but also a large Muslim minority while Pakistan was established on the slogan of two nation theory which termed Muslims as a separate entity distant from Hindus which led to the achievement of their separate homeland in the form of Pakistan.

The violent partition and differences on territorial boundaries gave a hostile start to their relations among each other which continue till date. Both the countries remained involving in multiple border skirmishes including three major wars in which one war

\footnotetext{
* Syed Jazib Shamim, M.Phil. student, Department of History (Gen), University of Karachi

** Muhammad Farooq, M.Phil. student, Department of Political Science, University of Karachi
} 
resulted in the disintegration of the United Pakistan in 1971. However, various attempts were made to normalize the relations among both the states but every time some critical events jeopardized the peace process.

Both the countries announced their entry in the nuclear countries club by conducting a series of nuclear tests in May 1998 and became sixth and seventh nuclear powers.

\section{The Process of Nuclear Armament}

The whole process of nuclear armament in the subcontinent began in India. In early 1950 's India initiated its nuclear program and established Bhaba Research Institute. ${ }^{1}$ In 1956, India became the first South Asian country to have a research reactor with enriched uranium supplied by the United States. After China's nuclear test in 1964, India expedited its nuclear program to counter the threat of emerging China and Pakistan simultaneously but propagating to the international community that the nuclear capability of India would be for peaceful purposes not for military purposes. ${ }^{2}$ India conducted its very first nuclear test in Pokhran, Rajhastan with the code name "Smiling Budha".

Pakistan's reaction was highly strong to the Indian nuclear test since it would have been a quite dangerous equation for Pakistan especially right after the disintegration of Pakistan. The then President of Pakistan, Zulfiqar Ali Bhutto announced to formally initiate Pakistan's nuclear program and said:

We will defend our country using any means necessary and build a nuclear capability second to none. We will eat grass for 1000 years, if we have to, but we will get there. ${ }^{3}$

Pakistan signed an agreement with France in 1974 for the construction of a nuclear processing plant to formally start the process of acquiring the nuclear capability but this whole process was sabotaged by the American government by pressurizing the French and Pakistani governments to cancel this agreement. UK also advised Islamabad to cancel this agreement. Pakistan facing heavy pressure from the foreign powers refused to cancel this agreement resulting into US cancelled military and economic assistance to Pakistan. France later gave in to the foreign pressure and cancelled the contract. Going one step ahead, US Secretary of State Dr. Henry Kissenger had threatened the then Prime Minister Bhutto that United States would make a horrible example of him if he went ahead with the nuclear program which he did and then later on it was claimed by Pakistan Peoples Party that the threat was actually carried out by overthrowing Bhutto's regime and later giving him death sentence since that judgment still remains as the most controversial decision in the history of Pakistan's judiciary. ${ }^{4}$

1 Amin Shahid "The EU's policy on Nuclear Prolifetaion and the Nuclearization of South Asia" in Naveed Ahmed Tahir, (ed.), European Union-Asia Relations in the 21st Century: Problems Prospects and Strategies, Karachi: ASCE, University of Karachi , 2000, p.229

2 Amin Shahid, Pakistan Foreign Policy, Karachi Oxford Press Karachi, 2007, p.78

3 Ibid.

4 Amin Shahid, The EU's policy, Op.cit, p.231 
After Bhutto's government, Pakistan was in huge pressure by the International community to halt its nuclear program but suddenly the scenario got a 360 degrees turn when Soviets invaded Afghanistan and US direly needed Pakistan as its main frontline ally in this proxy war in 1979. This historical event could be considered as a game changer in the nuclear history of Pakistan which allowed Pakistan to continue its nuclear program smoothly having no restrictions from the US, even US congress issued certification that Pakistan was not trying to develop nuclear capability. India, being annoyed from the shift in US policies towards Pakistani nuclear program, officially affirmed its right to produce nuclear weapons. ${ }^{5}$

In the late 1980's Pakistan has acquired the nuclear technology according to their nuclear scientists, but refrained to public it and building nuclear weapons. In 1988, tensions between both the states were very much diffused when son of Indira Gandhi and daughter of Zulfiqar Ali Bhutto, Rajiv Gandhi and Benazir Bhutto respectively met in a meeting in Islamabad to resolve the outstanding issues and signed an agreement not to attach on nuclear facilities of each other. However, soon after the withdrawal of the Soviet forces from Afghanistan, USA again taking a U-turn in its policies, demanded from Pakistan to roll back its nuclear program. Islamabad reacted strongly to this demand and rejected the pressure from the US and international community over its nuclear program. Seeing Islamabad's refusal to halt its nuclear program, US applied sanctions on Pakistan under Presseler Amendment, however the former failed to stop the latter to discontinue its nuclear program by all means.

Comprehensive Test Ban Treaty (CTBT) was presented to the global community after the deliberations and negotiations of almost 44 years which called to prevent and ban every nuclear explosion or test at any place. ${ }^{6}$ This treaty could be termed as a failure as both the countries who were aimed to be stopped from conducting nuclear tests, didn't sign the treaty and later on conducted nuclear tests. The global community ignored the rigidness in the Indian stance of not signing the NPT and CTBT but started exerting pressure on Pakistan to sign the CTBT but the latter refused to do so unconditionally. During these negotiations, India successfully tested its latest Prithvi intermediate range nuclear missile having the capacity of carrying a nuclear payload to target the whole of Pakistan and China. Islamabad responded to this action by successfully testing its two advanced nuclear ballistic missiles.

A hardliner extremist political party of India, BJP came to power in March, 1998 with a strong anti-Pakistan sentiment and policy. BJP government formally tested its nuclear weapons on 11 and 13 May, 1998 in Pokhran, Rajhastan. This event came as a great surprise and shock to the whole international community especially United States of America since they failed to predict about it. ${ }^{7}$ Prime Minister of India, Atal Bihari Wajpaye termed these tests vital to ensure Indian security. Global community including US strongly condemned the Indian tests and imposed a variety of sanctions on New Delhi, many countries called back their ambassadors for consultation on emergent

5Farmer. B.H. Pakistan Foreign Relation with India' in South Asia, Op.cit, p. 456

6 Amin Shahid, The EU's policy, Op.cit,p.234-235

7UpretiB.C. "Contemporary South Asia”, Kalinga Publication New Delhi, 2004,p.119 
situation in the region. Being a major ally of Pakistan, Chinese government also condemned these attacks and urged the countries around the world to exert pressure on India to halt its nuclear program. However, interestingly France, Russia and UK, being the nuclear powers other than US and China remained silent on this issue and didn't impose any sanction on India. ${ }^{8}$ European Union also gave a strong reaction on these tests and termed these tests as a great danger to the global peace and the region. Germany cancelled talks with India on development aid of around \$ 169.2 million; Swedish government cancelled a three year assistance agreement with India worth \$ 119 million while Norway, Denmark and Holland also stopped financial assistance to India.

Islamabad rejecting all international pressures tested its nuclear capability in the late May 1998 and announced its formal entry in the nuclears' club.

India and Pakistan emerged as world's sixth and seventh officially declared nuclear powers. The global community widely criticized the Pakistani response and imposed sanctions. Even other South Asian countries including Sri-Lanka, Nepal, Maldives and Bangladesh felt highly insecure from these tests while Bhutan congratulated India for the tests.

Reaction of the Global Community on Indian and Pakistan nuclear tests:

Following are the statements of some of the major political figures and leaders in 1998, garnered from a variety of sources, from several countries that are most involved with the issue of India and Pakistan's recent nuclear tests.

\section{Indian Prime Minister Atal Vajpayee}

The [nonproliferation] treaties are discriminatory and hypocritical. Our hope is that those nations that want to continue their nuclear monopoly will accept that the same rules should apply to all. ${ }^{9}$

\section{Indian Defense Minister George Fernandes}

China is India's number-one threat. It is encircling India with missile and naval deployments of suspicious intent. ${ }^{10}$

\section{Bal Thackeray, Nationalist Leader from Bombay}

We have to prove that we are not eunuchs. ${ }^{11}$

\section{Pakistani Prime Minister Nawaz Sharif}

Today we have evened the score with India....I would like to again assure all countries that our nuclear weapons systems are meant only for self-defense.... ${ }^{12}$

8Keesing's Record of World Event, News Digest for June 1998. Vol.44, p.42-43

${ }^{9}$ Boston Globe, May 29, 1998

${ }^{10}$ TIME Magazine, May 25, 1998

${ }^{11}$ Ibid. 


\section{Chinese official statements}

Having signed the nuclear Test Ban treaty in 1995, we have been consistently opposed to nuclear tests. We knew there was a great possibility that Pakistan would follow [India's testing] because of the internal pressure its leaders face. But this is a rather difficult situation for China. We have a friendship with Pakistan, but we still have a strong stance against nuclear proliferation. ${ }^{13}$

\section{The United Nations Secretary General Kofi Annan}

This [India's and Pakistan's nuclear tests] is a step backward. The world needs fewer nuclear powers, not more of them. But the problem goes beyond India--I'm calling on India and Pakistan to sign the nuclear test-ban treaty before this problem spins out of control. $^{14}$

\section{Russian President Boris Yeltsin}

India is frankly a close friend of ours, and we enjoy very good relations. Their testing of a nuclear weapon was a great surprise. And when my visit to India takes place this year, I will do my utmost to somehow settle this problem. ${ }^{15}$

\section{U.S. Senator John McCain}

The recent testing by India and Pakistan bring the world closer to a nuclear confrontation than at any time since the Cuban missile crisis of $1962 .^{16}$

\section{U.S. President Bill Clinton}

To try to manifest your greatness by detonating atomic bombs when everybody else is trying to leave the nuclear age behind is just wrong. India and Pakistan must give up their arms race--a self-defeating cycle of escalation. ${ }^{17}$

\section{Former head of the International Atomic Energy Agency Hans Blix}

India is a great civilization, but that is not enough. They do not feel that they were treated as though they were in the same league [as the permanent five nations on the U.N. Security Council]. One could ask if the outside world could have satisfied India's wish to be considered a great power in a different manner. Are nuclear bombs the only way to assert greatness? ${ }^{18}$

\footnotetext{
${ }^{12}$ New York Times, May 30, 1998

${ }^{13}$ TIME, Op.cit.

${ }^{14}$ Ibid.

${ }^{15}$ Ibid.

${ }^{16}$ Boston Globe, Op.cit.

${ }^{17}$ New York Times, Op.cit.

${ }^{18}$ Ibid.
} 


\section{Post Nuclearization Scenerio}

Both the countries were forced to come to the table of negotiation soon after the tests in the background of immense economic sanctions; Indian Prime Minister Wajpaye visited Lahore to meet his Pakistani counterpart Nawaz Sharif and signed Lahore Declaration which stated following points:

1) The two sides shall engage in bilateral consultations on security concepts and nuclear doctrines with a view to developing measures for confidence building in the nuclear and conventional fields.

2) The two sides undertake to provide each other with advance notification in respect of ballistic missile tests, and shall conclude a bilateral agreement in this regard.

3) The two sides are fully committed to undertake national measures for reducing the risks of accidental or unauthorized use of nuclear weapons under their respective control.

4) The two sides further undertake to notify each other immediately in the event of any accidental, unauthorized or unexplained incident that could create the risk of a fallout with adverse consequences for both sides, or an outbreak of a nuclear war between the two countris as well as to adopt measures aimed at diminishing the possibility of such actions or such incidents being misinterpreted by the other.

5) The two sides shall establish the appropriate communication mechanism for this purpose.

6) The Two sides shall continue to abide by their respective unilateral moratorium on conducting further nuclear test explosions unless either side, in exercise of its national sovereignty, decides that extraordinary events have jeopardized its supreme interest. ${ }^{19}$

\section{Motives of Nuclear Arms Race}

\section{Indian Motive}

Although, there was no provocation at that point of time which led India to take this bold step which had severe consequences, this perception has been presented that India had security risks majorly from China and the emerging friendship bond of China and Pakistan was a serious threat to India's security, this axis could have been dangerous for a non-nuclear India which led to India's nuclear program. If we carefully analyze, we may find loopholes in this perception since China posed no threat to India except a border crisis. It was India who had he aim of acquiring supremacy over the region especially Pakistan, Therefore, India decided to join the nuclear club. India was also lobbying to earn a permanent spot in the United Nations Security Council so India saw this nuclear test as an opportunity to present its case strongly for the permanent seat of Security Council.

19 Effendi Maria Saifuddin, Pakistan India Peace Process: Summits in Focus(1999-2005) Regional Studies (Islamabad) Vols. Xxiv,No.3,summer,2006,p.81 


\section{Pakistani Motive}

Although, these tests were condemned by the global powers, more emphasize of the global community was to stop Pakistan from retaliatory action on these tests which may possibly be the nuclear tests from the Pakistani side to deter the Indian supremacy in the region.

Islamabad was carefully monitoring the global situation and contemporary developments after the Indian nuclear tests. Strong national pressure was built on the government of Nawaz Sharif to give a befitting reply to India by conducting nuclear tests in response. On the other hands, global powers mainly US, Japan and European Union was pressurizing Islamabad not to conduct the nuclear tests despite accepting the major security threat to Pakistan and imbalance of power emergence after the Indian nuclear tests. Islamabad was warned of severe economic sanctions in case of nuclear tests while a heavy financial packages were also offered if they resist the temptation of retaliatory tests. The widening imbalance and disparity in the conventional weapons between India and Pakistan has gone one step ahead with New Delhi armed with nuclear weapons and creating a great power imbalance in the region. More to detriot the situation, Indian politicians started threatening Pakistan with strong words soon after becoming a nuclear state. Indian Interior Minister L.K. Advani stated "India's bold and decisive step to become a nuclear weapon state has brought about a qualitative new stage in Indo-Pak relations, particularly in finding a solution to the Kashmir Problem. It signifies India's resolve to deal firmly and strongly with Pakistan's hostile design and activities in Kashmir". The chief Minister of Indian occupied Kashmir also called Indian government to launch a decisive military strike on Pakistan to end the issue of Kashmir once and for all.

Internally, all the religions and right wing parties started to exert strong pressure on the Nawaz government and threatened to launch a movement to overthrow the government if it delays the nuclear tests. The public opinion was strongly in favor of the nuclear tests while the military and bureaucracy were also applying pressure to execute the nuclear tests. The government couldn't rely on the vague assurances from the West especially US who has let down Pakistan in the wars of 1965 and 1971 against India.

Islamabad was highly vulnerable without a nuclear power, it was quite evident in the given scenario. In order to re-create a balance of power in the subcontinent and a sentiment of self-defense, Pakistan detonated its nuclear weapons at Chaghi on May 28th and 30th, 1998. Prime Minister addressed the nation saying "We have settled the account of nuclear blasts by India, for the safety of our nation. He added that whatever happened in Hiroshima and Nagasaki would be avoided if Japan had nuclear weapons. ${ }^{20}$

\section{Differences in the Motives}

This is an undeniable fact that the motives of the both nuclear programs were extremely different. New Delhi strived to become a nuclear power to achieve regional supremacy

20 Dawn, May 29, 1998. 
and predominant position especially over Pakistan, its historic arch rival while on the other side Pakistan had no intentions of achieving regional supremacy but faced serious security threats from India since its inception, fought three wars with India and lost its eastern wing in the war of 1971 with India.

Islamabad's policy related to Indian threat rapidly increased after 1971 demise, increasing gap between conventional weapons was also an evident factor in this regard. The most feasible option to counter Indian threat and expansion designs in the region was to acquire nuclear capability to deter all possible Indian threats and coercion.

Just as India argued rather misleadingly that they needed to acquire the nuclear capability to counter threats from the emergind China, Pakistan had rather astrong and undeniable security driven threats from India. Islamabad always remained cautious for its security which was strongly justified since it shared borders with India, Russia and Afghanistan, all having non-friendly ties with Pakistan. Pakistan also felt threatened to sign NPT seeing limited and rather dual role of US towards Pakistan. US, as its major ally could have provided a strong defense umbrella to Pakistan to deter Indian threats, in that scenario it was not easy for the decision makers sitting in Islamabad to sign the NPT.

Despite initiating nuclear program, Pakistan also continued side by side efforts to stop this nuclear arms race in the region. Pakistan proposed several proposals which are given bellow:

- $\quad$ Establishment of a Nuclear Weapon Free Zone (NWFZ) in 1974 and repeated this proposals in 1976, 1987, 1990 and 2003 but in vain.

- Pakistan agreed to sign NPT conditionally if India signs NPT too with bilateral/joint agreements to full scope safeguards and inspections. This offer was given to India three times from 1984 to 1987 by the Zia ul-Haq regime but India rejected it.

- $\quad$ Bilateral acceptance of complete IAEA safeguards in 1979.

- Mutual inspection of each other's nuclear facilities in 1979.

- Offering India for a No War Pact in 1981 but again India refused.

- $\quad$ Bilateral treaty to ban all sorts of nuclear tests in 1987

- Non-manufacturing or test of nuclear weapons in 1987 and1991.

- Idea of South Asian Zero Missile Zone in 1994 . $^{21}$

Despite these constant efforts of Pakistan, India never showed a single intend to make the region, a nuclear free zone which made Pakistan to retaliate in that manner to deter Indian

21 Effendi Maria Saifuddin, Pakistan India Peace Process: Summits in Focus(1999-2005) Regional Studies (Islamabad) Vols. Xxiv,No.3,summer,2006,p.61 
nuclear supremacy. A major factor was also the increasing gap in the conventional military capabilities of India and Pakistan guaranteeing Indian mighty edge over Pakistan if the both nations go to war in the near future. In the scenario of India and Pakistan both having nuclear capability would promote to stop the threats of conventional wars that could be lead to nuclear standoff.

\section{Dual Standard of the West Over Indo Pak Nuclear Tests}

Upon analyzing carefully, we may observe that the reaction of West over the nuclear programs and then nuclear tests of both the countries was quite different and they had dual standards. The western powers ignored the aims of Indian nuclear program that were not defensive but to achieve regional supremacy while didn't pay attention to the increasing security threats to Pakistan when Pakistan decided to initiate its nuclear program in self-defense. Pakistan never sought the nuclear power in the first place or even before 1974 when India conducted its first nuclear test. At that point of time, Pakistani leadership realized that it needs to have nuclear capability to counter Indian supremacy in the region which poses serious threats to Pakistan's security as a state especially in the background of dismemberment of Pakistan in 1971.

The western powers exerted maximum pressure to Pakistan to halt its nuclear program instead of stopping Indian actions to disturb the power equilibrium in the region. Neither these powers did effective measures to gain parity with India in conventional arms. Even after the tests, the response of the major world powers including US, UK, France and Russia was muted revealing their pro Indian and anti-Pakistan policy.

The greatest region of this dual policy of the West was the emerging China. China was emerging as an economic giant and a competitive military force having the nuclear capability posing a serious threat to the western supremacy in the world. The western powers wanted a strong and nuclear India to counter the Chinese supremacy in the region but seeing its arch rival who also happened to be a close ally of China, acquiring nuclear capability in self-defense was not acceptable to the west at any cost.

\section{Economic Impact on India and Pakistan Due to Defense Spendings}

India and Pakistan experienced continuous rivalry since their inception. This unending conflict has forced them to spend heavily in defense sector and military especially nuclear program. Despite heavy spending on budget which even greatly compromised the socio-economic development of both the nations, this is evident that these spending never provided the state of foolproof security to both the states. Militancy, terrorism and insurgencies have continued to destabilize both the states and more to add on, they continue on spending heavily on their defense budget which is compromising its social and economic benefits.

Dire need of the time is that both the countries must sit together and work on confidence building measures so that this shift from military development to socio-economic development could take place. 
In 2017, Pakistan has a population of 200 million while India has 1.2 billion inhabitants. In Pakistan, the defense spending is more than the spending in the sectors of education and health while India has just minimized its defense spending from the spending in education and health sectors. Still, India is the biggest military spender in Asia being the world's greatest importer of weapons.

Despite the region of subcontinent having world's largest working age population, a quarter of world's middle class consumers and largest proportion of youth, its facing the challenges of poverty and robust economic growth majorly due to the military spending.

\section{Threat of Nuclear War}

\section{Background}

With both the nations equipped with nuclear capability, the threat of nuclear war between India and Pakistan is undeniable keeping in view their chain of events since their inception.

India never accepted the division of the subcontinent and it was evident.

This is indeed an undeniable reality that India never accepted Pakistan's emergence as they were aiming to rule the whole subcontinent and make Muslims like second class citizens in the Hindu majority state but due to the visionary leadership of Jinnah, their evil designs were failed and Pakistan came into existence. Indian mentality of Akhand Bharat was quite evident as a resolution was passed in the All India Congress Working Committee on 14th June 1947 that stated:

Geography and the mountains and the seas fashioned India as she is, and no human agency can change that shape or come in the way of her final destiny. Economic circumstances and the insistent demands of the International Affairs make the unity of India still more necessary. ${ }^{22}$

Hindu Maha Sabha passed a same sort of resolution that stated:

India is one and indivisible and there will never be peace unless and until the separated are brought back into the Indian Inion and made integral parts thereof. $^{23}$

These two clear cut resolutions passed right on the verge of establishment of Pakistan and division of the subcontinent clearly exposes the mindset of the fore fathers of India who never accepted the formation of Pakistan and openly called for their greater aim of Akhand Bharat.

After Pakistan's inception, India stopped Pakistan's financial assets and Indian leaders were expecting Pakistan to bankrupt and request for succession with India. On the other hand, India captured Junagarh and Hyderabad State forcefully from Pakistan and then

22V.P.Memon, The Transfer of Power in India, Orient Longsman Calcutta,1957,p.384

23Pande, Aparna,Explaining Pakistan Foreign Policy, Routledege, New York,2011,p.14 
Kashmir to challenge Pakistan's sovereignty right after its independence. Pakistan fought with all these challenges with courage and didn't let it shatter despite various serious problems and issues posed by India on economic and military fronts.

India secretly had made designs of East Pakistan's disintegration and its establishment had worked day and night tirelessly to accomplish this task. It has now been proven that India had a secret role in the disintegration of Pakistan and the leader of Awami League Shaikh Mujeeb-ur-Rehman had close contacts and secret affiliation with Indian establishment in this regard.

RAW backed the Hindu minority who played a vital role in motivating Bengali Muslims against West Pakistan. More importantly, RAW funded Sheikh Mujib-ur-Rahmans' general elections in 1970 and the members of his party, Awami League. His six points created prejudice among Bengali people especially against West Pakistan. ${ }^{24}$

After the separation of Bangladesh, PM of the exile government Tajuddin was also criticized by many Bengali officers due to his pro-Indian policies. Prime Minister Shaikh Mujib highly paid tribute to Indira Gandhi's efforts in the independence of Bangladesh right after he assumed office in Bangladesh. On the other hand, Indira Gandhi was found openly announcing that "We have taken the revenge of a thousand years", and "we have drowned the two-nation theory in the Bay of Bengal."

Soon after disintegration of Pakistan, India conducted nuclear tests in 1974 at Pokhran with code name "Smiling Budha".

The chain of events proves that India could go to any limit may it be to use nuclear weapons to devastate and hurt Pakistan leading to its demise and their dream of reestablishment of the United Subcontinent or Akhand Bharat. The top leadership of the Bharatiya Janata Party (BJP), which is currently ruling India, has not only publicly denounced the two-nation theory but has also declared that it does not accept the partition of the Sub-Continent in 1947 which was based on this theory. On the same analogy, the BJP claims that Kashmir is an integral part of India. The BJP also advises the Muslims in India that they must stop looking towards Makkah and Medina as they can live only by accepting Hindutva. The BJP government, in order to assimilate the Muslim population in India with the Hindu majority, also intends to amend Muslim personal laws. A movement has also been launched in India, with the blessing of the BJP government, that all the Indians, irrespective of their religious beliefs, should call themselves Hindus, as they are the citizens of "Hindustan". The non-Hindus in India, particularly the Muslims, are also being advised that by adopting the Hindu faith they may ensure for themselves an honorable place in the country.

The chances of the nuclear war in post 1998 scenario were never out of option for both the countries. It was often argued that the extreme level of antagonism and hostility among them, repetitive use of force to settle disputes especially Kashmir issue are the

24 Rashid,Abu,RAW in Bangladesh-Portrait of an Aggressive Intelligence, Dakka,2005 
major reasons why more than 1 billion people residing in both the nations should be feared of a nuclear war.

Here are some events where nuclear war was a great possibility but avoided:

\section{1) Kargil Crisis 1999}

$24^{\text {th }}$ June 1999 proved to be the luckiest day in the history of Indo-Pak relations when a nuclear and deadly war between both the nations was avoided.

According to a report of Indian Express, an Indian Air Force Jaguar at that day, flying close to Line of Control, had to bomb its target located in Mushkoh valley near LoC, mistakenly that Jaguar locked its target on the Pakistan's forward army base Gultari in Azad Kashmir located 9 kilometers away from the LoC which was a major army base that was providing logistic support to the Pakistani army during the war.

What that Jaguar didn't know that, at that point of time Pakistan's top political and military leadership including Prime Minister Nawaz Sharif, Chief of Army Staff General Pervez Musharraf and Defense Secretary Lt. Gen. (R) Iftikhar Ali Khan were also present at that base.

At the height of 11,600 feet there, Nawaz Sharif accompanied by Musharraf, was on his first visit to the forward bases of the Pakistani army and addressed the troops. There were two Indian Air force Jaguars, one had lased the military base having Pakistani Prime Minister and Army Chief in it and the second Jaguar had to fire a laser guided bomb on it. The fate of more than 1 billion people was at stake but just before the bombing, another Jaguar with pilot Air Martial A.K. Singh came in contact with both the Jaguars, Singh has judged that the Jaguars are about to target the Pakistani territory by mistake, therefore he immediately asked the attacking Jaguar to bomb the target and come back. After returning to the base, it was confirmed through the video recording that the target lased was the Gulteri base where a large number of army men were listening to the speech of Prime Minister Sharif. ${ }^{25}$

Now, even to imagine that what would have happened if that jaguar had bombed the Gulteri base, eliminating top Pakistani political and military leadership in seconds, is dangerous. Pakistani military leadership would have immediately ordered to bomb New Delhi or the main cities of India to eliminate the Indian leadership in order to avenge the killing of their Prime Minister and Army Chief. India's response could have been a nuclear strike and then the whole subcontinent would have become a hub of nuclear attacks and strikes leading it to nuclear Armageddon with hundreds of million people killed and affected by the nuclear attacks on both sides.

\section{2) 2001-2002: Military Standoff}

In December 2001, a terrorist attack took place in the building of Indian parliament killing 12 people including the terrorists. India instantly claimed that the attack was

25 Indian Express, 25 July 2017 
conducted by Mujahideen or militants of Pakistan based militant outfits i.e. Lashkar-eTaiba and Jaish-e-Muhammad that were operational in Kashmir against Indian armed forces while Pakistan categorically denied the allegations of supporting these groups.

By early January 2002 India had mobilized over 500,000 troops and its three armored divisions along the $3,000 \mathrm{~km}$ frontier with Pakistan. India also placed its navy and air force on "high alert" and deployed its nuclear-capable missiles. Pakistan reacted in kind, concentrating forces along the line of control that divides Kashmir. The deployment, which included troops in the states of Rajasthan, Punjab and Gujarat, was the largest since the 1971 conflict between the two rivals. Over 300,000 Pakistani troops are also mobilized.

In May, Indian army camp was attacked by three gun men killing 34 people near Jammu. Indian army and government was too angered and furious on this that India expelled the Pakistani high Commissioner. Cross border shelling and artillery firing began to escalate killing both Indian and Pakistani soldiers. Pakistan Air force shot down an Indian unmanned aerial vehicle near Lahore border. Before the situation could have led towards a conventional then a nuclear war, Russia jumped in for mediation and the situation began to ease down as in October 2002, India started demobilize its forces from the border followed by Pakistan. Finally, a ceasefire agreement was signed in 2003 between India and Pakistan.

President Musharraf despite international pressure had openly threatened India that Pakistan will not be hesitant to use nuclear weapons if its need arises. Even after the standoff, Musharraf clearly admitted that he was considering using nuclear option at that point of time. Had Musharraf used the nuclear strikes option, the history of India and Pakistan would have been slightly different and many major cities including the capitals of both the states would have been wiped off.

\section{Conclusion}

It is quite evident that a nuclear all-out war between Islamabad and New Delhi is certainly not out of option. There were almost two scenarios where a nuclear all out war was just one step away but the 1.5 billion inhabitants of both the states were lucky on both the moments but will fate be always lucky and give lifelines every time, certainly not.

Not only more than billions of inhabitants of subcontinent will suffer from this war but the whole region will be affected. Therefore, there is a dire need of promotion of concrete and decisive dialogue and confidence building among both the states since this military rivalry has curtailed the level of socio-economic development of both the states to a greater extend.

The goal of a welfare state couldn't be achieved by both the countries without eliminating this rivalry. If European states which fought wars for hundreds of years could now remain in exemplary peace and harmony why India and Pakistan having their ideologies 
intact can't, develop friendly ties which will be in the interest of the 1.5 billion people residing in the region.

\section{Bibliography}

Cheema, Zafar Iqbal (2010) India Nuclear Deterrence: Its Evaluation, Development, Implications for South Asian Security. New York: Oxford University Press.

Ganguly, Sumit and S. Paul Kapur (ed.), Nuclear Proliferation in South Asia, New York: Routledge, 2009.

Goswami, Namrata, (2006) "The Essence of the South Asian Nuclear Debate", Institute for Defense Studies and Analysis, Vol. 30, Issue. 3

Jaspal, Zafar Nawaz (2009). Paradox of Deterrence: India-Pakistan Strategic Relations. Strategic Studies, 29(4), 46-71.

Krepon, Michael and Chris Gagne,(ed) (2003) Nuclear Risk Reduction in South Asia, New Delhi: Stimson Centre

Rana, Shazia, (2010) "India and Pakistan's Nuclear Relationship Establishing a Stable Nuclear Deterrent and Prospects for Peace", University of Manitoba.

Sridharan, E., (2007) The India - Pakistan Nuclear Relationship, New Delhi: Routledge

Matinuddin, Kamal (2002) The Nuclearization of South Asia, New York: Oxford University Press.

Waltz, Kenneth N., (2003) The Spread of Nuclear Weapons: A Debate Renewed, New York: W.W. Norton

Carranza, Mario E., An Impossible Game: Stable Nuclear Deterrence After the Indian and Pakistan Tests, Spring- Summer 1999.

Chakma, Bhumitra, (2009) Pakistan's Nuclear Weapons, New York: Routledge

Effendi Maria Saifuddin, Pakistan India Peace Process: Summits in Focus(1999-

2005) Regional Studies (Islamabad) Vols. Xxiv,No.3,summer,2006. 